\title{
The association of follicle stimulating hormone receptor $(F S H R)$ gene polymorphism of on egg productivity in hybrid chicken (Gallus gallus gallus, Linnaeus 1758)
}

\author{
RIKHA RISKI KURNIA ${ }^{1}$, INDRA LESMANA ${ }^{1}$, ADITYA RAHMAN ERNANTO ${ }^{1}$, \\ AYUDHA BAHANA ILHAM PERDAMAIAN ${ }^{1}$, TRIJOKO ${ }^{2}$, BUDI SETIADI DARYONO ${ }^{1, \bullet}$ \\ ${ }^{1}$ Laboratory of Genetics and Breeding, Faculty of Biology, Universitas Gadjah Mada. Jl. Teknika Selatan, Sekip Utara, Sleman 55281, Yogyakarta, \\ Indonesia. Tel.: +62-274-580839, Fax.: +62-274-6492355, "email: bs_daryono@ mail.ugm.ac.id, ayudha.bahana.i@ mail.ugm.ac.id \\ ${ }^{2}$ Laboratory of Animals Systematic, Faculty of Biology, Universitas Gadjah Mada. Jl. Teknika Selatan, Sekip Utara, Sleman 55281, Yogyakarta, \\ Indonesia
}

Manuscript received: 13 October 2020. Revision accepted: 11 February 2021.

\begin{abstract}
Kurnia RR, Lesmana I, Ernanto AR, Perdamaian ABI, Trijoko, Daryono BS. 2021. The association of follicle stimulating hormone receptor (FSHR) gene polymorphism of on egg productivity in hybrid chicken (Gallus gallus gallus, Linnaeus 1758). Biodiversitas 22: 1221-1226. Pelung chicken genetics Improvement by selective breeding to Layer Lohmann Brown was successfully

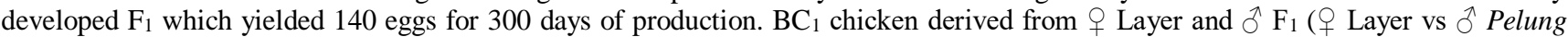
chicken). Polymorphism on $\mathrm{cFSHR}$ gene promoter was potential genetic marker candidate to assist the selection. This research aims to study the $\mathrm{BC}_{1}$ chicken egg-related traits performance for 16 weeks and study the correlation of $\mathrm{c} F S H R$ polymorphism to egg productivity. FSHR gene promoter was showed using sanger sequencing. Chicken were grouped based on their haplotype. Chicken were maintained in battery cage for observation of egg production. The results show that there is a difference of $\mathrm{BC}_{1}$ chicken $\mathrm{DOC}$ weight from different egg weight. The six SNP polymorphisms exist on cFSHR gene promoter fragments on 10, 51, 59, 121, 233, 331 nucleotides and conducted 7 haplotype group. The highest egg production in $\mathrm{BC}_{1}$ chicken on TTGCYA and lowest egg production on TTGYYG haplotype. Based on the correlation test there was a positive correlation at $\mathrm{p}>0.05$ between $\mathrm{BC}_{1}$ chicken TTGCYA haplotype with egg production and positive correlation at $\mathrm{p}<0.05$ between $\mathrm{BC}_{1}$ TAGTTA haplotype with egg length.
\end{abstract}

Keywords: Backcross, cFSHR gene promoter, egg productivity, hybrid chicken

\section{INTRODUCTION}

Chicken eggs are one of the economically important products in Indonesia. Egg price is relatively affordable compared with other sources of animal protein. The consumption of chicken eggs increased in 2015 by $3.57 \%$ per year while the consumption of local chicken eggs during $1996-2015$ on average decreased by $2.62 \%$ per year. Layer chicken egg consumption in Indonesia is higher than the local chicken eggs, this is because the price is relatively more expensive and limited in number.

Indonesia is known as the largest chicken germplasm center after China and India. This is evidenced by the presence of various types of local chickens spread in Indonesia with different morphological characters, such as Pelung chicken in Cianjur, West Java (Daryono et al. 2020), Kokok-Balenggek chicken in Solok District, West Sumatra, and Kedu chicken in Temanggung, Central Java (Ulfah et al. 2016). Local chicken in Indonesia has low productivity, so it has not been able to serve as a national food source. Therefore, it is necessary to perform genetic improvement to support the independence of the provision of food sources of animal protein.

Marker Assisted Selection (MAS) approach can accelerate the selection process by analyzing the interrelationship between quantitative traits and genetic variations. Chicken egg productivity was one of the interesting quantitative traits. Laboratory of Genetics and Breeding, Faculty of Biology, Universitas Gadjah Mada (UGM) since 2006 was perform breeding program to produce new chicken lines with local chicken qualitative character but have broiler fast growth rate (Utama et al. 2018; Tanjung et al. 2019; Perdamaian and Daryono 2020). Hybrid chicken $\left(F_{1}\right)$ derived from female broiler vs male Pelung, has a faster growth rate than Pelung, but its plumage color varies and still resembles a broiler. Another breeding scheme was brown layer chicken to produce $F_{1}$ hybrid chicken, which possesses an appropriate growth rate (Perdamaian et al. 2017). It is also necessary to use brown layer chicken as female parent to produce hybrid chicken with high egg productivity.

In our previous study using High-Resolution Melt (HRM) approach, hybrid chicken derived from crossing Layer Lohmann Brown to male Pelung has improved follicular development than Pelung chicken (data not shown). Those follicular development related to the different frequency of alleles in FSHR gene promoter polymorphism. That hybrid chicken has high egg productivity which produces approximately 140 eggs during 300 days of production (unpublished data). Back Crossing hybrid chicken to Layer Lohmann Brown was necessary to produce First Back Cross $\left(\mathrm{BC}_{1}\right)$ chicken which 
hopely possesses higher accumulated of egg quantitative traits.

One of importance genes related to eggs productivity, follicle-stimulating hormone receptor (FSHR) gene express protein which serve as receptor of follicle-stimulating hormone (FSH). The FSH role was to regulate follicle development and recruitment in the ovary (Lee et al. 2019; Guo et al. 2020). Polymorphism in the follicle-stimulating hormone receptor $(F S H R)$ gene was widely reported to affect egg productivity-related traits in chicken (Lee et al. 2011; Lee et al. 2019). Polymorphism on the $181 \mathrm{~A}>\mathrm{T}$ of FSHR positively correlates to the Beijing You chicken breed egg productivity (Lee et al. 2011).

In this research, FSHR gene polymorphism was investigated for egg quality and productivity in the $\mathrm{BC}_{1}$ lines of Indonesian hybrid chicken.

\section{MATERIALS AND METHODS}

This research was conducted in April 2017-June 2019, Lohman Brown and $F_{1}$ hybrid chicken (Figure 1) mating were done in breeding facility located at Innovation Center of Agro Technology, Universitas Gadjah Mada (PIAT UGM), Yogyakarta, Indonesia. Eggs were collected and artificially incubated. Molecular analysis was done at Laboratory of Genetics and Breeding, and Central Laboratory (FALITMA) of Faculty of Biology, Universitas Gadjah Mada, Yogyakarta, Indonesia.

\section{Hens maintenance}

Standard broiler chicken feed (AD II, Japfa, Indonesia) was used for raising Day Old Chicken (DOC) of $\mathrm{BC}_{1}$ chicken. Ten chicken was given free access of food and water. Ten female chickens of adult $\mathrm{BC}_{1}$ line were kept in semi-intensive $4 \times 4$ meters pens and adequate ventilation at PIAT UGM. Natural lighting with no special photoperiodization treatment was chosen. Chickens were maintained in battery cage for 4 months from the start laying period.

\section{Egg weight}

In this research, the weight of female Lohmann Brown chicken eggs was discriminated against for early selection of $\mathrm{BC}_{1}$ chicken line. Eggs with more than or equal to 60 grams in insert in group $\mathrm{A}$, while eggs less than 60 grams in insert in group B. This grouping aims to determine whether there is any influence of egg weight on the weight of DOC. Independent T-test was used to differentiate the two groups.

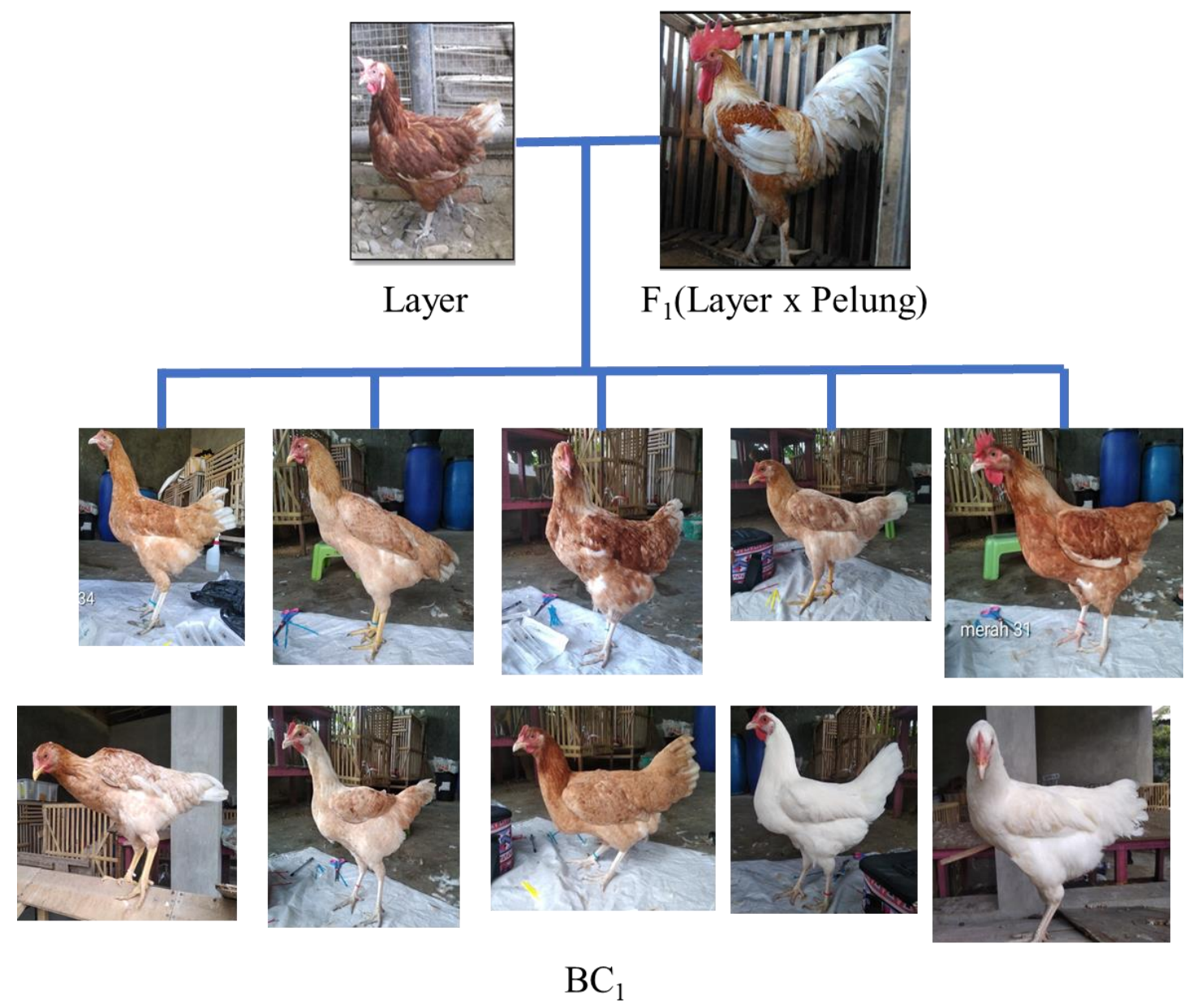

Figure 1. The picture of $\mathrm{BC}_{1}$ chicken, female Layer and $\mathrm{F}_{1}$ (Layer $\mathrm{x}$ Pelung) 


\section{Egg width and length}

Egg produced from $\mathrm{BC}_{1}$ chicken was collected and its weight and length recorded each haplotype. Chicken egg length and width were measured using vernier caliper.

\section{Genomic DNA isolation}

Genomic DNA was extracted using Chelex method followed our previous report (Ernanto et al. 2018). with the addition of TE Buffer in the sample, centrifuge was done at $13.000 \mathrm{rpm}$ for 13 minutes. Supernatant was discarded, and $5 \%$ Chelex solution, $18 \mu \mathrm{L} 0.05 \mathrm{M}$ DTT, $2 \mu \mathrm{L}$ proteinase $\mathrm{K}$ $(10 \mathrm{mg} / \mathrm{mL})$ was added to the remaining pellet. The solution was then vortexed prior to incubated at $56^{\circ} \mathrm{C}$ for 2 hours with vortexed every 15 minutes. Incubation was prolonged into $100{ }^{\circ} \mathrm{C}$ boiling water for 8 minutes before homogenized for 30 seconds. Samples were centrifuged at $13,000 \mathrm{rpm}$ for 3 minutes and its supernatant was transferred into new microtubes and stored at $-20{ }^{\circ} \mathrm{C}$ before use.

\section{Genomic DNA amplification}

Gene of interest was amplified using thermocycler (BioRad, US) with specific primer (IDT, Malaysia). $25 \mu \mathrm{L}$ cocktail consisted of $12.5 \mu \mathrm{L}$ Master mix PCR kit (KAPATaqTM; US), $2.5 \mu \mathrm{L}$ forward (5'-TCA-GCT-GAGGCC-TGT-GAT-TTC-3) and reverse (5'-GGA-GAGAAG-CGA-GGC-TGA-TTT-3') primer, $10 \mu \mathrm{L}$ DNA template $( \pm 50 \mathrm{ng} / \mu \mathrm{L})$, and $10 \mu \mathrm{L}$ ddH2O.

The PCR reaction was performed on a thermal cycler with a pre-denaturation condition at $95{ }^{\circ} \mathrm{C}$ for 3 minutes. Then 30 cycles of denaturation at $95{ }^{\circ} \mathrm{C}$ for 15 seconds, annealing at $60{ }^{\circ} \mathrm{C}$ for 20 seconds, and extension at $72^{\circ} \mathrm{C}$ for 25 seconds. Post extension for 5 minutes at $72{ }^{\circ} \mathrm{C}$. Horizontal DNA electrophoresis was done at $2 \%$ agarose gel.

\section{Sanger sequencing of FSHR gene}

The obtained PCR product was quoted to Sanger sequencing (1st BASE, Malaysia). FSHR gene promoter $(348$ bp) were sequenced with forward (5'TGCCTGGGTGTAGGACATA-3') and reverse (5'CACCCTTCCTTGAAGGTC-3') primer. DNA Baser software was used to observe the presence of single nucleotide polymorphism (SNP).

\section{Statistical analysis}

The correlation test was done using SPSS 16.0 software to determine the relationship between the polymorphism of the $c F S H R$ gene promoter and the productivity of the hybrid chicken egg backcross1 at a 95\% confidence level.

\section{RESULTS AND DISCUSSION}

In this study, Backcross or $\mathrm{BC}_{1}$ chicken line was derived from crossing female Lohmann Brown chicken with $\mathrm{F}_{1}$ (female Lohmann Brown x male Pelung) chicken. Lohmann Brown chicken eggs weight were discriminated for early selection of $\mathrm{BC}_{1}$ chicken. The average weight of group A and group B DOC were significantly different at 99\% confidence level ( $\mathrm{p}<0.01)$. The result of this selection is chicken with higher body weight and good egg productivity than Pelung chicken which had $500 \mathrm{~g}$ body weight and around 30.17 eggs/23 weeks (Kilatsih et al. 2020).

Ten females of $\mathrm{BC}_{1}$ chicken has six different variations of the feather which was white $(9 \%)$, white and brown (27\%), brown (37\%), light brown (9\%), dark brown (9\%), and brown-gray color (9\%). Genomic DNA was extracted using the phenol-chloroform technique and amplified by using a conventional thermal cycler (Figure 2).

After amplified using conventional thermal cycler, PCR products were Sanger sequenced (Figure 3).

\section{TTCAGCTTGCTCAGGATTCAAGTGAGTCAACATCAGCAG AGTTACCCATGAAAATCCAGCTAGCGAGCTCACTTACCA TGCAGATGACTTACAAGCTGTGCATATCTTAAACTTATA ATAAATAAGGACTCAAAGATGGGGTTCAGTGTCCAGGCC TCATGATCATGATAATGTCCTTGAAGCTATTTCTTGAAC CTGTACCTCTTGTTGTGTAATAAATATTCATTCTGTTTA TTTTCCAATGATAAAATTAGCTCACTGGTCTCC}

Figure 3. The partial sequence of $F S H R$ promoter gene of $\mathrm{BC}_{1}$ chicken
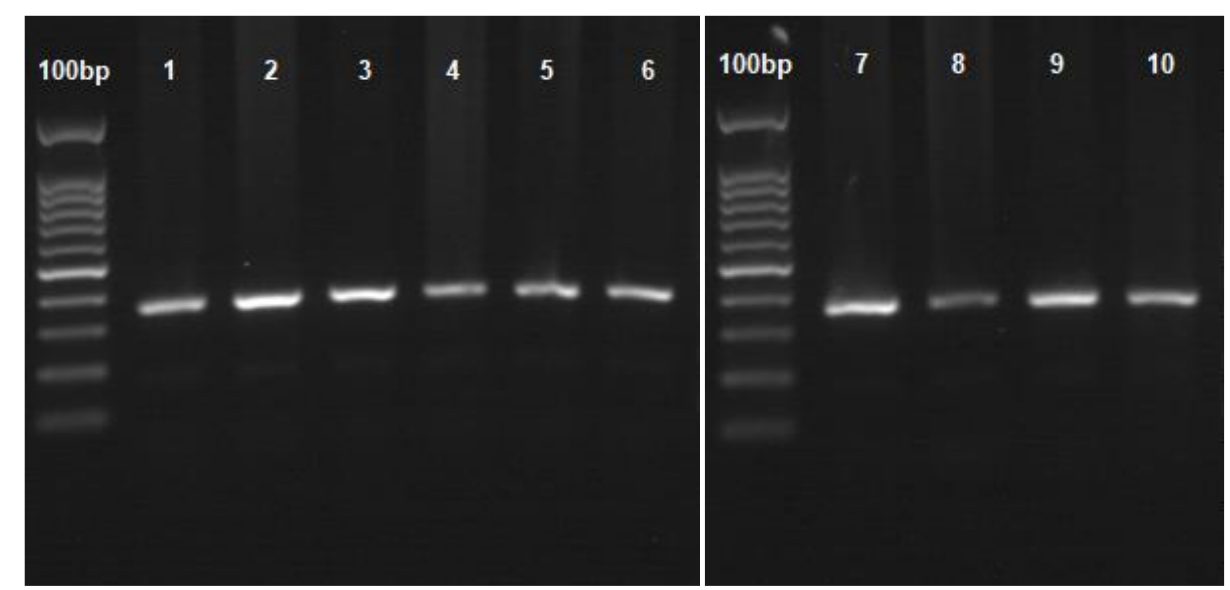

Figure 2. The DNA band of chicken $F S H R$ gene visualized by $2 \%$ agarose gel electrophoresis shift. Line 1 to 10 indicate the $\mathrm{BC}_{1}$ chicken 


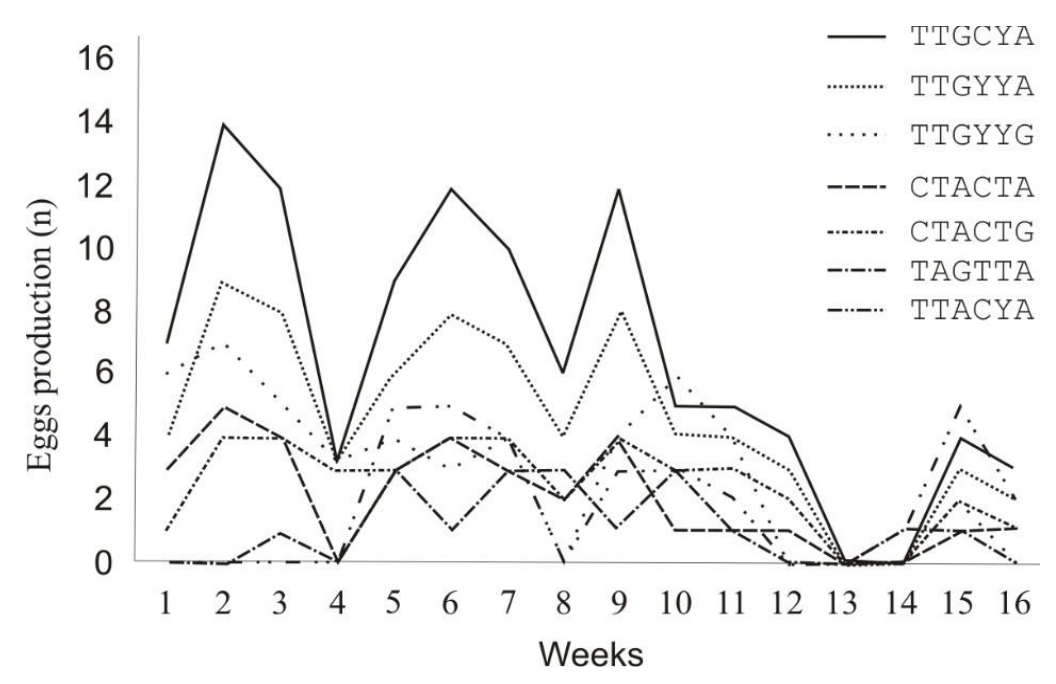

Figure 4. The egg productivity of $\mathrm{BC}_{1}$ chicken each haplotype group

Table 1. The genotype of $\mathrm{BC}_{1}$ chicken according to $\mathrm{c} F S H R$ gene polymorphism

\begin{tabular}{ccccccc}
\hline $\begin{array}{c}\text { Chicken } \\
\text { taq }\end{array}$ & \multicolumn{7}{c}{ SNP position } \\
\cline { 2 - 6 } & $\mathbf{1 0}$ & $\mathbf{5 1}$ & $\mathbf{5 9}$ & $\mathbf{1 2 1}$ & $\mathbf{2 3 3}$ & $\mathbf{3 3 1}$ \\
\hline 1 & CC & TT & AA & CC & TT & AA \\
2 & TT & TT & AA & CC & CT & AA \\
3 & TT & TT & GG & CT & CT & GG \\
4 & TT & TT & GG & CT & CT & AA \\
5 & TT & TT & GG & CC & CT & AA \\
6 & TT & TT & AA & CC & CT & AA \\
7 & TT & AA & GG & TT & TT & AA \\
8 & TT & TT & GG & CT & CT & AA \\
9 & CC & TT & AA & CC & TT & GG \\
10 & TT & TT & GG & CC & CT & AA \\
\hline
\end{tabular}

Table 2. The haplotype of $\mathrm{BC}_{1}$ chicken based on $\mathrm{cFSHR}$ gene polymorphism

\begin{tabular}{cc}
\hline Haplotype & Population percentage $(\boldsymbol{\%})$ \\
\hline TTGCYA & $20 \%$ \\
TTGYYA & $20 \%$ \\
TTACYA & $20 \%$ \\
CTACTG & $10 \%$ \\
CTACTA & $10 \%$ \\
TAGTTA & $10 \%$ \\
TTGYYG & $10 \%$ \\
\hline
\end{tabular}

FSHR gene sequences of ten $\mathrm{BC}_{1}$ chickens were analyzed using DNA Baser software. The genotype of $\mathrm{BC}_{1}$ chicken based on FSHR gene polymorphism can be seen in Table 1.

Based on Table 1. $\mathrm{BC}_{1}$ chicken has six polymorphisms on fragment DNA of $10,51,59,121,233$, and 331. The recapitulation of these SNP further grouped into seven haplotypes. The result of grouping of individuals based on haplotype can be seen in Table 2 .
$\mathrm{BC}_{1}$ chickens were comprised of seven haplotypes. Of which, three haplotypes consisted of two individuals, and four haplotypes consisted of one individual. The eggs productivity of $\mathrm{BC}_{1}$ chickens of each haplotype was observed for 16 weeks. The eggs production $\mathrm{BC}_{1}$ chickens each haplotype per week for 16 weeks is presented in Figure 4.

In this study, the egg production of $\mathrm{BC}_{1}$ chickens began recorders after $11^{\text {th }}$ week of egg production then observed for 16 weeks. There was a trend line showing the cumulative average number of eggs for 16 weeks. In general, $\mathrm{BC}_{1}$ chickens with TTACYA haplotype has two production peaks at $6^{\text {th }}$ and $15^{\text {th }}$ week. In $\mathrm{BC}_{1}$ chickens with CTACTG and CTACTA haplotypes have three peaks. First production peak of CTACTA occurring at the $2^{\text {nd }}$ week while CTACTG at $3^{\text {rd }}$ week of observation. The second and third peaks are the same at $9^{\text {th }}$ and $15^{\text {th }}$ week of observation.

$\mathrm{BC}_{1}$ chickens with TTGYYA and TTGCYA haplotypes have the same 3 peaks at 2,8 , and 15 weeks. BC $_{1}$ chickens with haplotype TAGTTA have 2 peaks at 8 and 15 weeks. In haplotype TTGYYG of $\mathrm{BC}_{1}$ chickens has 2 peaks that are on weeks 2 and 10. The average number of cumulative productions of $\mathrm{BC}_{1}$ chicken in each haplotype group for 16 weeks presented in Figure 5.

The cumulative average production of $\mathrm{BC}_{1}$ chicken egg for 16 weeks reached as many as 39.11. local chicken can produce as many as 25 eggs and the layer chicken can produce as many as 75 eggs at the same age which is maintained by the litter system. Figure 6 shows that the TTGCYA haplotype has an average high egg production compared to the other six haplotypes. The TTGYYG haplotype is the second-highest, followed by the CTACTG haplotype. There are 3 groups of haplotypes with the same amount of egg productivity: TTACYA, CTACTA, and TTGYYA. Then haplotype TAGTTA relatively low productivity eggs. Thus, the TTGCYA haplotype can be used as a marker or marker in egg productivity selection. 

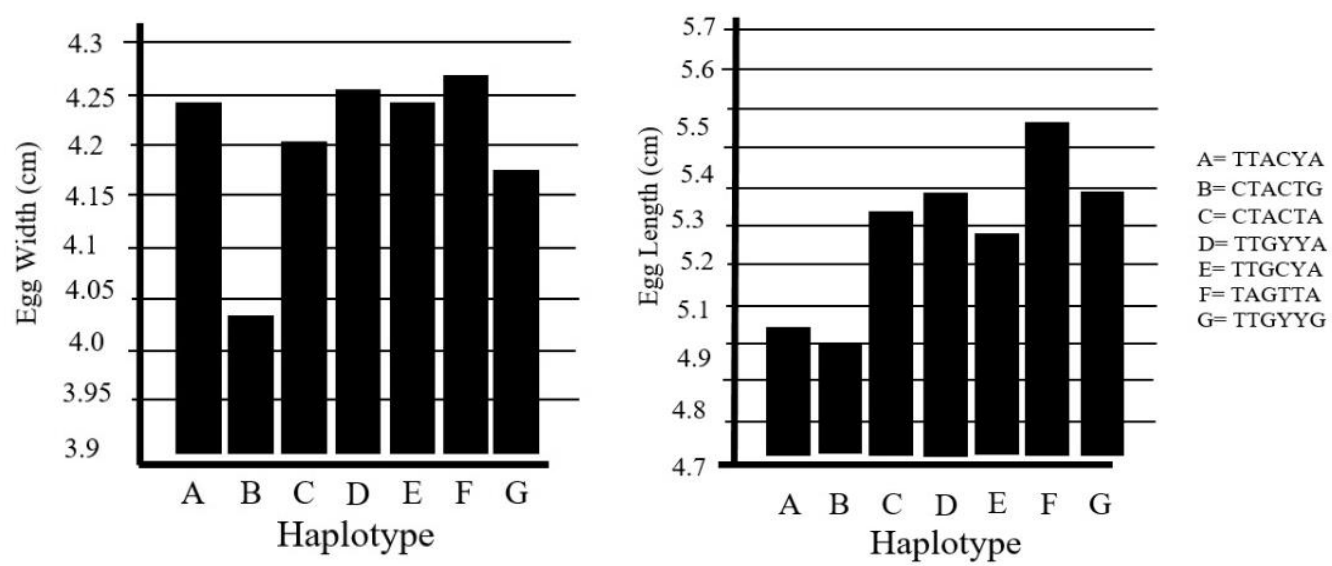

Figure 5. The average egg width (left) and length (right) of each haplotype group of $\mathrm{BC}_{1}$ chicken

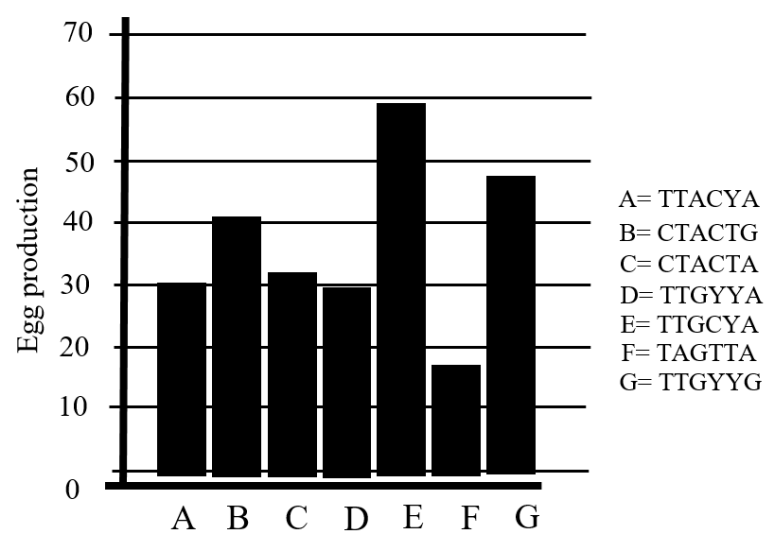

Figure 6. The average number of egg production each hybrid chicken $\mathrm{BC}_{1}$ haplotype group

Based on Figure 3 it is known that the TAGTTA haplotype has a higher average egg length than the other six haplotypes. The correlation test using SPSS 16.0 shows a positive correlation $(r=0.725)$ and shows the level of significance at the level of trust $p<0.05$. The correlation test between chicken haplotype and average egg width using SPSS showed that the positive correlation was very weak $(r=0.194)$ and did not show the significance level ( $p$ $>0.05)$.

\section{Discussion}

Chicken crossbreeding aims to produce hybrid which possesses heterosis effect (Isa et al. 2020). The breeding program for layer chicken was exhaustive job since heritability of egg-related traits is low to medium (Du et al. 2020). In this study, $\mathrm{BC}_{1}$ chicken line was derived from crossing female Lohmann Brown chicken with $\mathrm{F}_{1}$ (female Lohmann Brown x male Pelung) chicken. Originally, this crossing aim to produce a chicken with more homozygous plumage and eggs productivity related traits but $\mathrm{BC}_{1}$ remains had plumage color variation.
There was a positive correlation between the weight of eggs against the resulting hatching weight. The weightier the egg will produce weightier DOC. This is because the eggs with a high weight have a high egg yolk and egg white's composition, while the eggs with a small weight have a yellow and egg whites are slightly composition. Egg yolk is a source of energy used for the growth of day-old chicken during the hatching process (Ayeni et al. 2020; Duman and Şekeroğlu 2017).

Haplotype is an interaction between alleles in DNA fragments. Haplotype analysis that known demonstrates the identification of more efficient genetic variations compared with one single nucleotide polymorphism (SNP) analysis. Grouping of haplotypes $\mathrm{BC}_{1}$ chickens was performed on a battery cage for egg production observation for 16 weeks.

The productivity of $\mathrm{BC}_{1}$ chicken was still relatively low around $39.11 \mathrm{egg} / \mathrm{chicken}$, this is because not able to produce the same amount of egg production as its parent $F_{1}$, but its egg productivity has been above the productivity of Pelung chicken. Low egg productivity levels $\mathrm{BC}_{1}$ chickens can be caused by different maintenance systems using a cage system or battery enclosure.

The promoter of FSHR gene was widely studied in poultry (Liu et al. 2015; Liu et al. 2018; Li et al. 2019; Sun et al. 2020; Du et al. 2020). Several studies found causative DNA mutations at promoter region of FSHR gene associated with egg-related traits. These mutations affect gene expression (Xu et al. 2017; Brady et al. 2020). The miRNA expression pattern in ovarian tissue was also reported to be linked to egg production (Wu et al. 2016). Study in Khorasan native fowl, mutation in exon 1 of IL-2 compromises the protein structure (Tohidi and Javanmard 2020). Expression level of FSHR is marker for human ovarian cancer (Wei et al. 2018).

In this study, correlation test result shows a weak positive correlation $(r=0.250)$ but does not show the level of significance $(\mathrm{p}>0.05)$. This suggests that the presence of polymorphisms in $\mathrm{c} F S H R$ gene promoters although single nucleotide polymorphism will affect allele interactions in egg productivity. 
The results showed a positive trend between polymorphism of cFSHR gene promoter and egg production although it did not show the level of significance at $\mathrm{p}<0.05$. This research needs to be further developed to see the promoter activity at mRNA level. It is known for its polymorphism impact on gene expression with a large chicken population. Further research must evaluate the Food conversion ratio (FCR) of $\mathrm{BC}_{1}$ chicken since feed contributes up to $80 \%$ of total cost.

The eggs productivity of $\mathrm{BC}_{1}$ chicken was higher than Pelung chicken, but lower than its predecessor $\mathrm{F}_{1}$ and Lohmann Brown. There was polymorphism within six SNPs in the cFSHR gene promoter in the 10, 51, 59, 121, 233, and 159 nucleotides, and there was a positive correlation at $\mathrm{p}>0.05$ between polymorphism of $\mathrm{cFSHR}$ gene promoter fragment to egg number, egg weight, egg width and positive correlation at $\mathrm{p}<0.05$ between polymorphism of $\mathrm{cFSHR}$ gene promoter to egg length.

\section{ACKNOWLEDGEMENTS}

The authors want to thank Gama Ayam Research Team for valuable assistance during chicken handling, Faculty of Biology, Universitas Gadjah Mada (UGM) for providing molecular genetics laboratory, and Pusat Inovasi Agro Teknologi (PIAT) UGM for providing breeding facility. In 2019 this research was financially supported by Applied Research grant (Penelitian Terapan/PT No. 2830/UN1.DITLIT/DIT-LIT/LT/2019) of Ministry of Research Technology and Higher Education of Indonesia.

\section{REFERENCES}

Ayeni AO, Agbede JO, Igbasan FA, Onibi GE, Adegbenro M. 2020 Effects of storage periods and positioning during storage on hatchability and weight of the hatched chicks from different egg sizes. Bull Natl Res Cent 44: 101. DOI: 10.1186/s42269-020-00362-4.

Brady K, Long JA, Liu HC, Porter TE. 2020. Differences in in vitro responses of the hypothalamo-pituitary-gonadal hormonal axis between low- and high-egg-producing turkey hens. Poult Sci 99 (11): 6221-6232. DOI: 10.1016/j.psj.2020.08.048.

Daryono BS, Muslih M, Perdamaian ABI. 2020. Vocalization characters and forkhead box P2 (FoxP2) polymorphism in Indonesian crowing type chicken (Gallus gallus domesticus). Iranian J Appl Anim Sci 10 (2): 131-140

Du Y, Liu L, He Y, Dou T, Jia J, Ge C. 2020. Endocrine and genetic factors affecting egg laying performance in chickens: A review. $\mathrm{Br}$ Poult Sci 61: 538-549. DOI: 10.1080/00071668.2020.1758299.

Duman M, Şekeroğlu A. 2017. Effect of egg weights on hatching results, broiler performance and some stress parameters. Brazilian J Poult Sci 19 (2): 255-262. DOI: 10.1590/1806-9061-2016-0372.

Guo C, Liu G, Zhao D, Mi Y, Zhang C, Li J. 2019. Interaction of folliclestimulating hormone and stem cell factor to promote primordial follicle assembly in the chicken. Front Endocrinol 10: 1-13. DOI: 10.3389/fendo.2019.00091.

Isa AM, Sun Y, Shi L, Jiang L, Li Y, Fan J, Wang P, Ni A, Huang Z, Ma H, Li D, Chen J. 2020. Hybrids generated by crossing elite laying chickens exhibited heterosis for clutch and egg quality traits. Poult Sci 99: 6332-6340.

Kilatsih R, Perdamaian ABI, Joko T, Purwanto SH, Daryono BS. 2020. Effect analysis of Prolactin (PRL) gene polymorphisms on chicken egg productivity (Gallus gallus domesticus) BC1 from crossbreeding between Pelung and Layer chicken. Iranian J Appl Anim Sci 10 (4): 717-726.

Li X, Lu Y, Liu X, Xie X, Wang K, Yu D. 2019. Identification of chicken FSHR gene promoter and the correlations between polymorphisms and egg production in Chinese native hens. Reprod Domest Anim 54 (4): 702-711. DOI: 10.1111/rda.13412.

Li G, Sun DX, Yu Y, Liu WJ, Tang SQ, Zhang Y, Wang YC, Zhang SL, Zhang Y. 2011. Genetic effect of the follicle-stimulating hormone receptor gene on reproductive traits in Beijing You chickens. Poult Sci 90 (11): 2487-2492. DOI: 10.3382/ps.2010-01327.

Liu L, Li D, Gilbert ER, Xiao Q, Zhao X, Wang Y, et al. 2015. Effect of monochromatic light on expression of Estrogen Receptor (ER) and Progesterone Receptor (PR) in ovarian follicles of chicken. PLoS ONE 10 (12): e0144102. DOI: 10.1371/journal.pone.0144102.

Liu L, Xiao Q, Gilbert ER, Cui Z, Zhao X, Wang Y, Yin H, Li D, Zhang H, Zhu Q. 2018. Whole-transcriptome analysis of atrophic ovaries in broody chickens reveals regulatory pathways associated with proliferation and apoptosis. Sci Rep 8: 7231. DOI: 10.1038/s41598018-25103-6.

Perdamaian ABI, Saragih HTSSG, Daryono BS. 2017. Effect of varying level of crude protein and energy on insulin-like growth factor-i expression level in Indonesian hybrid chicken. Intl J Poult Sci 16 (1): 1-5. DOI: 10.3923/ijps.2017.1.5.

Perdamaian ABI, Daryono BS. 2020. Polymorphism of prolactin and prolactin promoter genes and its association with broodiness and body weight in Indonesian chicken lines. Iranian J Appl Anim Sci 10: 311316.

Sun Y, Liu R, Lu X, Hu Y, Zhao G, Zheng M, Chen J, Wang H, Wen J. 2013. Associations of polymorphisms in four candidate genes with carcass and/or meat-quality traits in two meat-type chicken lines Anim Biotechnol 24: 53-65. DOI: 10.1080/10495398.2012.742909.

Tanjung A, Saragih HTSG, Trijoko, Soenarwan HP, Widianto S, Mahardhika IWS, Daryono BS. 2019. Short Communication: Polymorphism of myostatin gene and its association with body weight traits in a hybrid of GAMA chicken (Gallus gallus domesticus Linn. 1758). Biodiversitas 20 (11): 3207-3212. DOI: 10.13057/biodiv/d201113.

Tohidi R, Javanmard A. 2020. Identification of novel mutations in IL-2 gene in Khorasan Native Fowls. Poult Sci J 8 (1): 1-8. DOI: 10.22069/PSJ.2020.16789.1465.

Ulfah M, Kawahara-Miki R, Farajalllah A, Muladno M, Dorshorst B, Martin A, Kono T. 2016. Genetic features of red and green junglefowl and relationship with Indonesian native chickens Sumatera and Kedu hitam. BMC Genom 17 (1): 320-328. DOI: 10.1186/s12864-0162652-z.

Utama IV, Perdamaian ABI, Daryono BS. 2018. Plumage uniformity, growth rate and growth hormone polymorphism in Indonesian hybrid chickens. Intl J Poult Sci 17 (10): 486-492. DOI: 10.3923/ijps.2018.486.492.

Wei S, Lai L, Yang J, Zhuandi G. 2018. Expression levels of folliclestimulating hormone receptor and implication in diagnostic and therapeutic strategy of ovarian cancer. Oncol Res Treat 41: 651-654. DOI: $10.1159 / 000490810$.

Wu N, Gaur U, Zhu Q, Chen B, Xu Z, Zhao X, et al. 2016. Expressed microRNA associated with high rate of egg production in chicken ovarian follicles. Anim Genet 48 (2): 205-216. DOI: 10.1111/age.12516.

Xu J, Gao X, Li X, Ye Q, Jebessa E, Abdalla BA, Nie Q. 2017. Molecular characterization, expression profile of the FSHR gene and its association with egg production traits in Muscovy duck. J Genet 96: 341-351. DOI: 10.1007/s12041-017-0783-x. 